\title{
Clinical features and predictors for disease natural progression in adults with Pompe disease: a nationwide prospective observational study
}

Nadine AME van der Beek ${ }^{1,2^{*}}$, Juna M de Vries ${ }^{1,2}$, Marloes LC Hagemans ${ }^{2}$, Wim CJ Hop ${ }^{3}$, Marian A Kroos ${ }^{4}$, John HJ Wokke ${ }^{5}$, Marianne de Visser ${ }^{6}$, Baziel GM van Engelen', Jan BM Kuks ${ }^{8}$, Anneke J van der Kooi ${ }^{6}$, Nicolette C Notermans ${ }^{5}$, Karin G Faber ${ }^{9}$, Jan JGM Verschuuren ${ }^{10}$, Arnold JJ Reuser ${ }^{4}$, Ans T van der Ploeg ${ }^{2}$ and Pieter A van Doorn ${ }^{1}$

\begin{abstract}
Background: Due partly to physicians' unawareness, many adults with Pompe disease are diagnosed with great delay. Besides, it is not well known which factors influence the rate of disease progression, and thus disease outcome. We delineated the specific clinical features of Pompe disease in adults, and mapped out the distribution and severity of muscle weakness, and the sequence of involvement of the individual muscle groups. Furthermore, we defined the natural disease course and identified prognostic factors for disease progression.

Methods: We conducted a single-center, prospective, observational study. Muscle strength (manual muscle testing, and hand-held dynamometry), muscle function (quick motor function test), and pulmonary function (forced vital capacity in sitting and supine positions) were assessed every 3-6 months and analyzed using repeated-measures ANOVA.
\end{abstract}

Results: Between October 2004 and August 2009, 94 patients aged between 25 and 75 years were included in the study. Although skeletal muscle weakness was typically distributed in a limb-girdle pattern, many patients had unfamiliar features such as ptosis (23\%), bulbar weakness (28\%), and scapular winging (33\%). During follow-up (average 1.6 years, range $0.5-4.2$ years), skeletal muscle strength deteriorated significantly (mean declines of $-1.3 \%$ point/year for manual muscle testing and of $-2.6 \%$ points/year for hand-held dynamometry; both $p<0.001$ ). Longer disease duration (>15 years) and pulmonary involvement (forced vital capacity in sitting position $<80 \%$ ) at study entry predicted faster decline. On average, forced vital capacity in supine position deteriorated by $1.3 \%$ points per year $(p=0.02)$. Decline in pulmonary function was consistent across subgroups. Ten percent of patients declined unexpectedly fast.

Conclusions: Recognizing patterns of common and less familiar characteristics in adults with Pompe disease facilitates timely diagnosis. Longer disease duration and reduced pulmonary function stand out as predictors of rapid disease progression, and aid in deciding whether to initiate enzyme replacement therapy, or when.

Keywords: Acid a-glucosidase, Glycogen storage disease type II, OMIM number 232300, Lysosomal storage disorder, Disease progression, Natural course, Prognostic factors

\footnotetext{
* Correspondence: n.beek@erasmusmc.nl

${ }^{1}$ Department of Neurology, Center for Lysosomal and Metabolic Diseases,

Erasmus MC University Medical Center, 's-Gravendijkwal 230, 3015 CE,

Rotterdam, the Netherlands

${ }^{2}$ Department of Pediatrics, Center for Lysosomal and Metabolic Diseases,

Erasmus MC - Sophia Children's Hospital, University Medical Center,

Rotterdam, the Netherlands

Full list of author information is available at the end of the article
}

\section{Biomed Central}

(c) 2012 van der Beek et al.; licensee BioMed Central Ltd. This is an Open Access article distributed under the terms of the Creative Commons Attribution License (http://creativecommons.org/licenses/by/2.0), which permits unrestricted use, distribution, and reproduction in any medium, provided the original work is properly cited. 


\section{Background}

Pompe disease is a rare autosomal recessive metabolic disorder, whereby mutations in the GAA gene lead to partial or total absence of the lysosomal enzyme acid $\alpha$-glucosidase. The disease presents as a spectrum of phenotypes, ranging from a rapidly fatal phenotype in infants [1] to slower progressive phenotypes in older children and adults. [2,3] Many adults with Pompe disease are diagnosed late in life, when they are already in an advanced stage of the disease. While this may be due to clinicians' unawareness, it may also be explained by similarities in clinical presentation with other limbgirdle' diseases such as the limb-girdle muscular dystrophies (LGMD), Becker muscular dystrophy, or metabolic myopathies. [4] Our first objective was to optimize future diagnosis in this patient group by classifying their specific clinical features, and by delineating the distribution and severity of muscle weakness and the sequential involvement of individual muscle groups during the course of the disease.

Since 2006, enzyme replacement therapy (ERT) with recombinant human acid $\alpha$-glucosidase has been approved for the treatment of Pompe disease. In infants, treatment generally improves cardiorespiratory function and motor function, and prolongs survival. [5-8] In older children and adults ERT was shown to improve or stabilize skeletal muscle strength, muscle function and respiratory function. However, the magnitude of the therapeutic response varies between individual patients. [9-14] To fully assess the effects of enzyme therapy, and to decide whom to treat and when to start treatment, it is necessary to be optimally informed about the course of disease prior to treatment, and about factors influencing disease progression. We thus prospectively studied the natural disease course, and aimed to identify prognostic factors for faster disease progression and poor outcome in a large cohort of adult Pompe patients.

\section{Methods}

\section{Participants and study design}

We performed a single-center, prospective, cohort study, in which participation was open to all adults diagnosed with Pompe disease who had not yet received treatment with enzyme replacement therapy. Their diagnosis was confirmed by acid $\alpha$-glucosidase assay in leukocytes or fibroblasts and by mutation analysis. All patients were seen between October 2004 and August 2009 at Erasmus MC University Medical Center, the designated center of expertise for Pompe disease in the Netherlands. The interval between visits was three to six months. Patients were recruited either through neuromuscular centers in the Netherlands and Belgium, through the Dutch neuromuscular patient organization, or were referred to our Center by their treating physicians. The research protocol was approved by the Central Committee on Research Involving Human Subjects in the Netherlands (CCMO). All patients provided written informed consent.

Seven patients participated in the placebo arm of the randomized, placebo controlled trial on the safety and efficacy of alglucosidase alfa in late-onset Pompe disease. [13] Data on these patients collected during this period are included in the present analyses. We have previously reported long-term retrospective data on muscle strength and pulmonary function in 16 patients with Pompe disease. [15] While 12 of these patients participated in the current study, the present analyses were based solely on new, prospectively obtained data.

\section{Procedures}

We gathered information on the following: 1) the nature of first symptoms and the age at which these had presented; 2) the age at which the diagnosis had been made; 3) duration of disease since onset of first symptoms; 4) the presence of specific clinical features such as scoliosis, bulbar involvement (defined as weakness of muscles involved in speech, chewing and swallowing), winging of the scapula (defined as a clearly visible protrusion of the scapula when the patient was in a resting position or was lifting the arms anteriorly or sidewards), muscle atrophy, or ptosis; 5) the use of a wheelchair or walking aids; 6) skeletal muscle strength; 7) the use of mechanical ventilatory support; 8) the number of hours of ventilatory support per day; 9) pulmonary function; 10) cardiac function; 11 ) acid $\alpha$-glucosidase activity in leukocytes and fibroblasts; 12) serum creatine kinase (CK); and 13) type of GAA mutation.

\section{Skeletal muscle strength and muscle function}

By manual muscle testing using the Medical Research Council (MRC) grading scale [16] (range 0-5; all patients were examined by $\mathrm{NvdB}$ or $\mathrm{JdV}$ ), we measured 25 different muscle groups throughout the body to define the distribution of skeletal muscle weakness and the severity of involvement of the separate muscle groups. We calculated a sumscore (range 0-130) for the muscle groups that were involved most: neck extensors, neck flexors, and bilateral shoulder adductors, shoulder abductors, shoulder exorotators, shoulder endorotators, elbow flexors, elbow extensors, hip extensors, hip flexors, hip abductors, hip adductors, knee flexors and knee extensors. This score was subsequently converted to a percentage of the maximum possible score. Although the abdominal muscles and trunk muscles were frequently involved, we did not include these muscle groups in the MRC sumscore since they were difficult to grade. 
Hand-held dynamometry (HHD) (Cytec dynamometer, Groningen, the Netherlands) was used as a second measure of muscle strength to examine the following muscle groups: neck extensors, neck flexors and bilateral shoulder abductors, elbow flexors, elbow extensors, hip flexors, hip abductors, knee flexors and knee extensors. The value (Newton) measured in each muscle group was expressed as a percentage of the median strength of healthy females and males [17], and then combined into a sumscore by averaging these for all 16 muscle groups, producing a score between 0 and 100 percent.

Muscle function was assessed using the Quick Motor Function Test (QMFT). [18] A total score (range 0-64) was obtained by adding the scores of all items. This was then expressed as a percentage of the maximum score.

\section{Pulmonary function}

Forced vital capacity (FVC) was measured using a Lilly type pneumograph (Viasys Healthcare, Würzburg, Germany) or the KoKo spirometry system (Ferraris Respiratory, Louisville, USA) with the patient in upright seated and supine positions, according to ATS/ERS standards. [19] Results were expressed as a percentage of predicted normal values. [20] A measured value below $80 \%$ of the predicted value was considered to be abnormally low. Seven male patients who were invasively ventilated were artificially allotted a FVC value of $10 \%$ - just below the least observed value - since their omission might have led to biased results. These seven patients were however excluded from the longitudinal analysis.

\section{Statistical analysis}

Baseline characteristics are summarized using descriptive statistics. Differences between males and females, and between patients with and without scapular winging, were assessed using $X^{2}$ tests (wheelchair use, use of mechanical ventilation, and presence of scoliosis, bulbar muscle weakness, scapular winging or ptosis) or MannWhitney tests (strength of individual muscle groups, MRC sumscore, HHD sumscore, QMFT sumscore, and FVC measured in sitting and supine positions). We used the Spearman's rank correlation coefficient $(\rho)$ to calculate the relationships between residual enzyme activity and rate of decline in muscle strength and pulmonary function, and between serum CK activity and age, muscle atrophy and disease duration. Longitudinal analysis of muscle strength and pulmonary function was performed using repeated measures ANOVA (random coefficient models). The annual changes are expressed in absolute percentage points ( $\mathrm{pp} / \mathrm{y})$. For subgroup analyses, patients were divided into groups on the basis of gender (male, female); wheelchair use (yes, no); use of mechanical ventilation (yes, no); age at first study visit ( $<50$ or $\geq 50$ years; taking the median as the cut-off point); disease duration ( $<15$ or $\geq 15$ years; taking the median as the cut-off point); MRC/HHD sumscore at study entry (categorization in tertiles); and FVC in sitting position at study entry $(<80$ or $\geq 80 \%$ predicted). Analyses were performed with SPSS for Windows (version 15, SPSS Inc., Chicago, IL) or SAS (version 9.1, SAS Institute Inc., Cary, NC). A p-value of $\leq 0.05$ was considered statistically significant.

\section{Results}

\section{Study population}

In order of referral, we included 91 adult Pompe patients from the Netherlands - representing virtually all known patients in the Netherlands - and three patients from Belgium. On average, there was a seven-year delay between the first noted symptoms of Pompe disease and the actual diagnosis. The characteristics of the study population are summarized in Table 1.

\section{Baseline measurements}

\section{Characteristic clinical features}

A substantial number of patients had less familiar features of Pompe disease, such as bulbar muscle weakness (28\%), prominent scapular winging (33\%, Figure $1 \mathrm{~b})$, or ptosis - not accompanied by external eye-movement disturbances (23\%; Figure 1c). Seventy-one percent of patients with scapular winging had bulbar muscle weakness, against $37 \%$ without scapular winging $(\mathrm{p}=0.001)$.

\section{Clinical distribution and severity of muscle weakness, and sequence of muscle involvement during the disease course}

Shoulder abductors, abdominal muscles, paraspinal muscles, hip flexors, hip extensors, hip adductors, and hip abductors were affected in more than $80 \%$ of all patients (Figure 2a). The strength of the quadriceps muscle was reduced in only $55 \%$ of patients. The muscles of the hands and feet were relatively spared, being affected in under $10 \%$ of patients. Abdominal muscles, paraspinal muscles - with exception of the neck extensors and neck flexors -, hip flexors, hip extensors, hip adductors and hip abductors were the most severely affected muscles (Figure 2b). The pattern of muscle weakness was symmetrical in $95 \%$ of patients, and the distribution of weakness did not differ between males and females. Relative to patients without scapular winging, patients with scapular winging had more severe involvement of the shoulder girdle musculature (trapezius muscle, deltoid muscle, pectoral muscle, shoulder exorotators, and shoulder endorotators; all $\mathrm{p}<0.02)$. The 'limb-girdle' and trunk muscles were affected early in the course of the disease, while the distal muscle groups - if they were involved at all - were affected late in the course of the disease (Figure 2c). 
Table 1 Characteristics of the study population $(n=94)^{a}$

\section{General characteristics}

\begin{tabular}{|c|c|}
\hline Gender (males) & $48(51 \%)$ \\
\hline Age at first study visit (years) & $51.1(38.3-60.6)$ \\
\hline Age at onset of symptoms (years) & $32.0(25.5-40.0)$ \\
\hline$\cdot<18$ years & $10(11 \%)$ \\
\hline$\cdot \geq 18$ years & $84(89 \%)$ \\
\hline Age at diagnosis (years) & $40.2(32.7-50.2)$ \\
\hline $\begin{array}{l}\text { Disease duration since onset of first symptoms } \\
\text { at first study visit (years) }\end{array}$ & $15.3(7.7-24.7)$ \\
\hline Time since diagnosis at first study visit (years) & $9.2(0.6-16.0)$ \\
\hline . 0 to 5 years & $41(44 \%)$ \\
\hline . 5 to 10 years & $15(16 \%)$ \\
\hline - 10 to 15 years & $10(11 \%)$ \\
\hline$\cdot>15$ years & $28(30 \%)$ \\
\hline Use of walking aids & $14(15 \%)$ \\
\hline Wheelchair use & $30(32 \%)$ \\
\hline Age at start of wheelchair use (years) & $49.0(43-56)$ \\
\hline Use of mechanical ventilation ${ }^{b}$ & $27(29 \%)$ \\
\hline Age at start of mechanical ventilation (years) & $48(38.5-57.5)$ \\
\hline \multicolumn{2}{|l|}{ First symptoms noted $^{c}$} \\
\hline Skeletal muscle weakness & $93(99 \%)$ \\
\hline - Difficulty running & $30(32 \%)$ \\
\hline - Difficulty performing sports & $22(23 \%)$ \\
\hline - Difficulty climbing stairs & $24(26 \%)$ \\
\hline - Difficulty walking & $15(16 \%)$ \\
\hline - Difficulty rising from an armchair & $11(12 \%)$ \\
\hline - Difficulty rising from a lying position & $9(10 \%)$ \\
\hline Fatigue & $17(18 \%)$ \\
\hline Muscle soreness / cramps & $16(17 \%)$ \\
\hline Respiratory failure & $1(1 \%)$ \\
\hline
\end{tabular}

Clinical features

\begin{tabular}{ll}
\hline Ptosis & $22(23 \%)$ \\
\hline Bulbar muscle weakness $^{d}$ & $26(28 \%)$ \\
\hline Scapular winging $^{d}$ & $31(33 \%)$ \\
\hline Scoliosis $^{\prime}$ & $22(23 \%)$ \\
\hline Increased lumbar lordosis & $62(66 \%)$ \\
\hline Prominent muscle atrophy & $53(56 \%)$ \\
\hline - Shoulder girdle / upper arms & $25(27 \%)$ \\
\hline - Trunk muscles & $27(29 \%)$ \\
\hline - Pelvic girdle / Upper leg (Figure 1a) & $40(43 \%)$ \\
\hline
\end{tabular}

\begin{tabular}{ll}
\hline Laboratory parameters & \\
\hline CK (U/l) & $449(279-1040)$ \\
\hline - Males & $493(237-715)$ \\
\hline - Females & $1.2(0.4-2.2)$ \\
\hline $\begin{array}{l}\text { a-glucosidase activity in leukocytes } \\
\text { (nmol glucose/h/mg protein) }^{\mathrm{e}}\end{array}$ \\
\hline
\end{tabular}

a-glucosidase activity in fibroblasts (nmol 4-MU/h/mg protein) $^{\mathrm{f}}$
Table 1 Characteristics of the study population $(n=94)^{a}$ (Continued)

\begin{tabular}{|c|c|}
\hline Genotype & \\
\hline $\begin{array}{l}\text { - c.-32-13T>G / very severe or potentially } \\
\text { less severe pathogenic mutation }\end{array}$ & $92(98 \%)$ \\
\hline - c.671G>A / c.525del & $1(1 \%)$ \\
\hline - unknown & $1(1 \%)$ \\
\hline $\begin{array}{l}\text { 4-MU: } 4 \text {-methylumbelliferyl-a-D-glucopyranos } \\
\text { a Data are number ( } \% \text { ) or median (IQR). }{ }^{b} \text { Mo } \\
\text { mechanical ventilation ( }\left(p=0.009 \text { ). }{ }^{c} \text { Two or } \mathrm{m}\right. \\
\text { these occurred within the same year. }{ }^{d} \text { More } \\
\text { winging and bulbar muscle weakness ( } p=0.0 \\
\text { to } 215 \mathrm{nmol} \text { glucose/h/mg protein. }{ }^{f} \text { control } \\
\text { protein. }\end{array}$ & $\begin{array}{l}\text { en used } \\
\text { ere counted if } \\
\text { had scapular } \\
\text { control range } 48 \\
\mathrm{~mol} 4-\mathrm{MU} / \mathrm{h} / \mathrm{mg}\end{array}$ \\
\hline
\end{tabular}

\section{Cardiac evaluation}

In a subset of 51 patients cardiac evaluation was performed, comprising electrocardiography, Holter monitoring, two-dimensional echocardiography, low-dose dobutamine stress echocardiography, and tissue Doppler imaging. One patient had a mild hypertrophic cardiomyopathy, while four other patients had minor cardiac abnormalities that could be attributed to advanced age, hypertension or preexisting cardiac pathology unrelated to Pompe disease $[21,22]$.

\section{Laboratory parameters}

Most patients had moderately increased serum CK; in two patients it was more than 10 times the upper limit of normal, while 10 had a normal serum CK. Serum CK activity was moderately inversely associated with age $(\rho=-0.71$, $\mathrm{p}<0.001)$, disease duration $(\rho=-0.45, \mathrm{p}<0.001)$, and the presence of muscle atrophy $(\rho=-0.53, \mathrm{p}<0.001)$.

\section{Prospective follow-up General aspects}

Prospective follow-up data for a period longer than six months were available for 66 patients (median 1.6 years, range 0.5-4.2 years), 52 of whom were followed for longer than one year, and 22 of whom for longer than two years. Within the follow-up period, one patient became wheelchair bound, mechanical ventilation was initiated in four patients, and eight patients needed to increase their number of hours of ventilation per day. One severely affected patient died due to pneumonia complicated by respiratory failure.

\section{Disease progression and predictors for disease outcome}

Muscle strength and muscle function At baseline, the MRC sumscore ranged from $39.2 \%$ to $100 \%$ (median $84.7 \%$, one patient had the maximum possible score). During follow-up, the MRC sumscore deteriorated by $1.3 \%$ points per year on average $(\mathrm{p}<0.001$; Figure $3 \mathrm{a})$. Baseline values for hand-held dynamometry ranged from $31.6 \%$ to $100 \%$ (median $77.0 \%$, three patients had the maximum score). Within the observed follow-up period, 

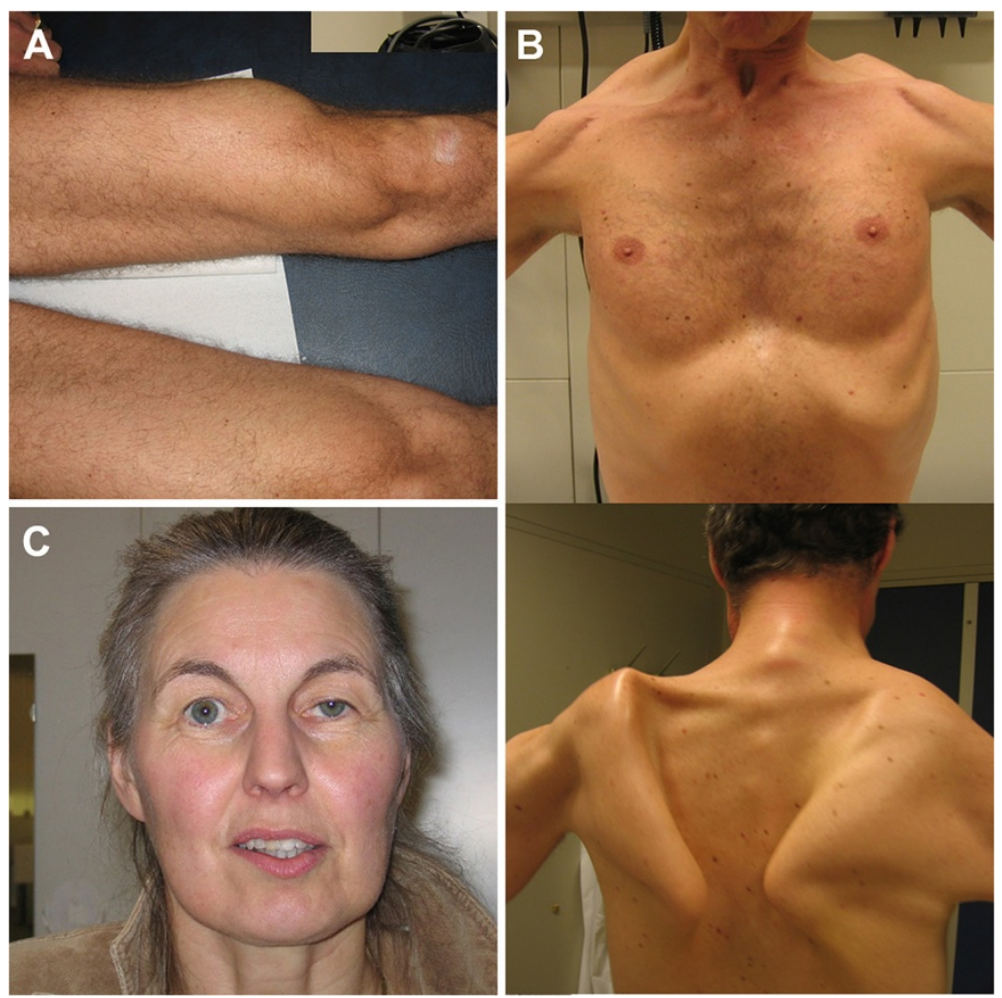

Figure 1 Clinical features in Pompe disease. Atrophy of the quadriceps muscle (A), scapular winging (B), and ptosis (C) as notable clinical features in adults with Pompe disease. Photographs are printed with permission of the patients.

HHD sumscore deteriorated by $2.6 \%$ points per year $(\mathrm{p}<0.001$; Figure $3 \mathrm{~b})$. With regard to the individual muscle groups, strength declined significantly in the elbow flexors, hip abductors, knee extensors and knee flexors, ranging from $-6.9 \mathrm{pp} / \mathrm{y}$ in elbow flexors to -2.5 $\mathrm{pp} / \mathrm{y}$ in knee extensors (Figure 4). Subgroup analysis (Table 2) revealed that the decline was faster in patients with a reduced pulmonary function at baseline (FVC $<80 \%)$ than in those with normal pulmonary function (-2.2 pp/y against $-0.6 \mathrm{pp} / \mathrm{y}$ for MRC sumscore $(\mathrm{p}=0.01)$, and $-4.5 \mathrm{pp} / \mathrm{y}$ against $-1.4 \mathrm{pp} / \mathrm{y}$ for HHD sumscore $(\mathrm{p}<0.01))$, and in patients who had had the disease for longer than 15 years compared to those who had been ill less long $(-2.1 \mathrm{pp} / \mathrm{y}$ against $-0.7 \mathrm{pp} / \mathrm{y}$ for MRC sumscore $(\mathrm{p}=0.04)$, and $-4.2 \mathrm{pp} / \mathrm{y}$ against $-2.0 \mathrm{pp} / \mathrm{y}$ for HHD sumscore $(\mathrm{p}<0.01))$. Baseline QMFT scores ranged from $16.7 \%$ to $100 \%$ (median $63.7 \%$ ). The changes that were found in muscle strength were however not reflected in changes in the QMFT (annual change $0.05 \%$ points, $\mathrm{p}=0.9$ ). In no subgroups was a significant decline observed.

Pulmonary function At baseline, FVC measured in sitting position was reduced ( $<80 \%$ of the predicted value) in 56 patients (60\%). The reduction in FVC was more prominent in males than in females (mean FVC 57.5\% predicted against $80.3 \%$ predicted, $\mathrm{p}<0.001$ ). Patients with scapular winging had significantly lower FVC than those without scapular winging (mean FVC 50.7\% predicted against $84.5 \%$ predicted, $\mathrm{p}<0.001)$. In supine position, 76 patients $(80 \%)$ had a reduced FVC. Changing from a sitting to a supine position, FVC fell in 21 patients by over $25 \%$, indicating possible diaphragmatic weakness. Neither was testing in the supine position attempted in 12 patients whose pulmonary function was already severely restricted in sitting position. We have recently reported more detailed data on pulmonary function in some of the study cohort. [23] The mean yearly change in FVC measured in supine position was $1.3 \%$ points $(\mathrm{p}=0.02)$, and for $\mathrm{FVC}$ in upright position $-1.0 \%$ points $(\mathrm{p}=0.06)$ (Figure 5$)$. The rate at which pulmonary function declined was consistent across subgroups. There was no significant association between the change in muscle strength or pulmonary function and residual enzyme activity (Spearman's rho for MRC sumscore -0.21, $\mathrm{p}=0.14$; for HHD sumscore $-0.51, \mathrm{p}=0.74$; for FVC in upright position $0.07, \mathrm{p}=0.65$; and for FVC in supine position $-0.32, \mathrm{p}=0.84$ ).

\section{Disease course variability}

In 59 patients progress of muscle weakness and pulmonary dysfunction could be compared. In nine patients 


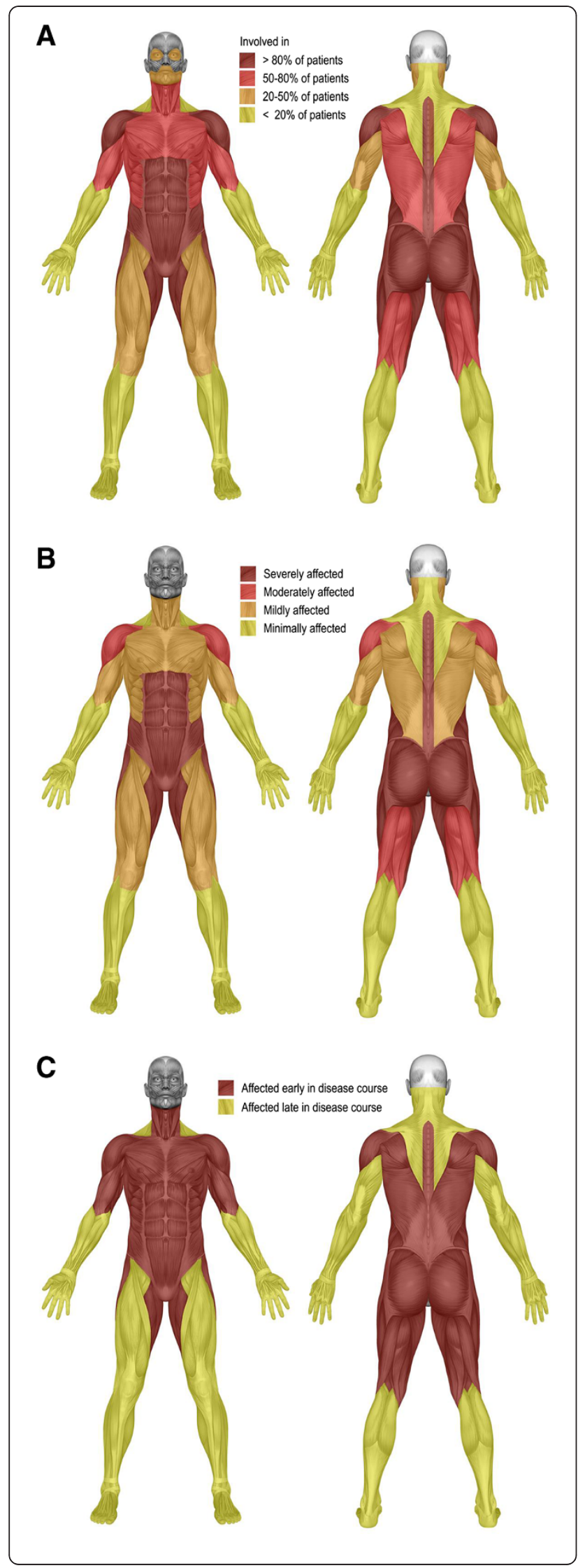

Figure 2 Muscle weakness in adults with Pompe disease.

Distribution of skeletal muscle weakness (A), severity of muscle weakness of the individual muscle groups (B), and involvement of the individual muscles over time (C) in 94 adults with Pompe disease.

(15\%; 4 males, 5 females), pulmonary function and muscle strength did not decline during the prospective follow-up period. Relative to the total group, they had a shorter disease duration from onset of symptoms (7.3 years against 15.5 years, $\mathrm{p}=0.03$ ). At baseline, the following had all been higher, though not significantly: FVC in sitting position $(88.1 \%$ against $78.6 \%)$; FVC in supine position (80.4\% against $61.1 \%)$; MRC sumscore $(87.2 \%$ against $83.4 \%)$; and HHD sumscore $(86.2 \%$ against $76.3 \%)$. In 28 patients (47\%), pulmonary function and skeletal muscle strength declined at a similar rate. In 22 patients $(37 \%)$ the course of pulmonary function and muscle weakness followed different courses, one deteriorating while the other remained stable, or one deteriorating faster than the other. Of the 50 patients who deteriorated during the follow-up period, eight ( 2 males, 6 females) had a relatively fast decline - more than 5 percentage points per year - in muscle strength, while a rapid decline in pulmonary function was seen in five patients ( 1 male, 4 females). There were no significant differences between these groups with regard to sex, age, age at onset of symptoms, duration of disease, length of prospective follow-up, level of residual enzyme activity, and the severity of pulmonary or skeletal muscle involvement at the start of the study.

\section{Discussion}

\section{Characteristic clinical features and pattern of muscle weakness}

Our study in 94 adults with Pompe disease - which included virtually all known adult patients in the Netherlands - shows that, generally speaking, muscle weakness typically fits a pattern of limb-girdle myopathy. Interestingly, our findings about the distribution of muscle weakness, based on clinical examinations, match those of CT and MRI studies. [24-26] We found weakness of the quadriceps muscle in $55 \%$ of patients only. This may have been due to our method of measuring muscle strength: whereas the advantage of the MRC score and HHD lie in the fact that they are easy for the clinician to use, quantitative muscle testing using QMT [13,27] may be more reliable in patients with only minor loss of strength.

Besides limb-girdle weakness, many patients had less familiar features, which are sometimes symptomatic of other neuromuscular diseases. Though ptosis has been reported in the literature in no more than seven adult patients to date [28-31], it was found in almost one quarter of our patients. Notably, while one might expect 

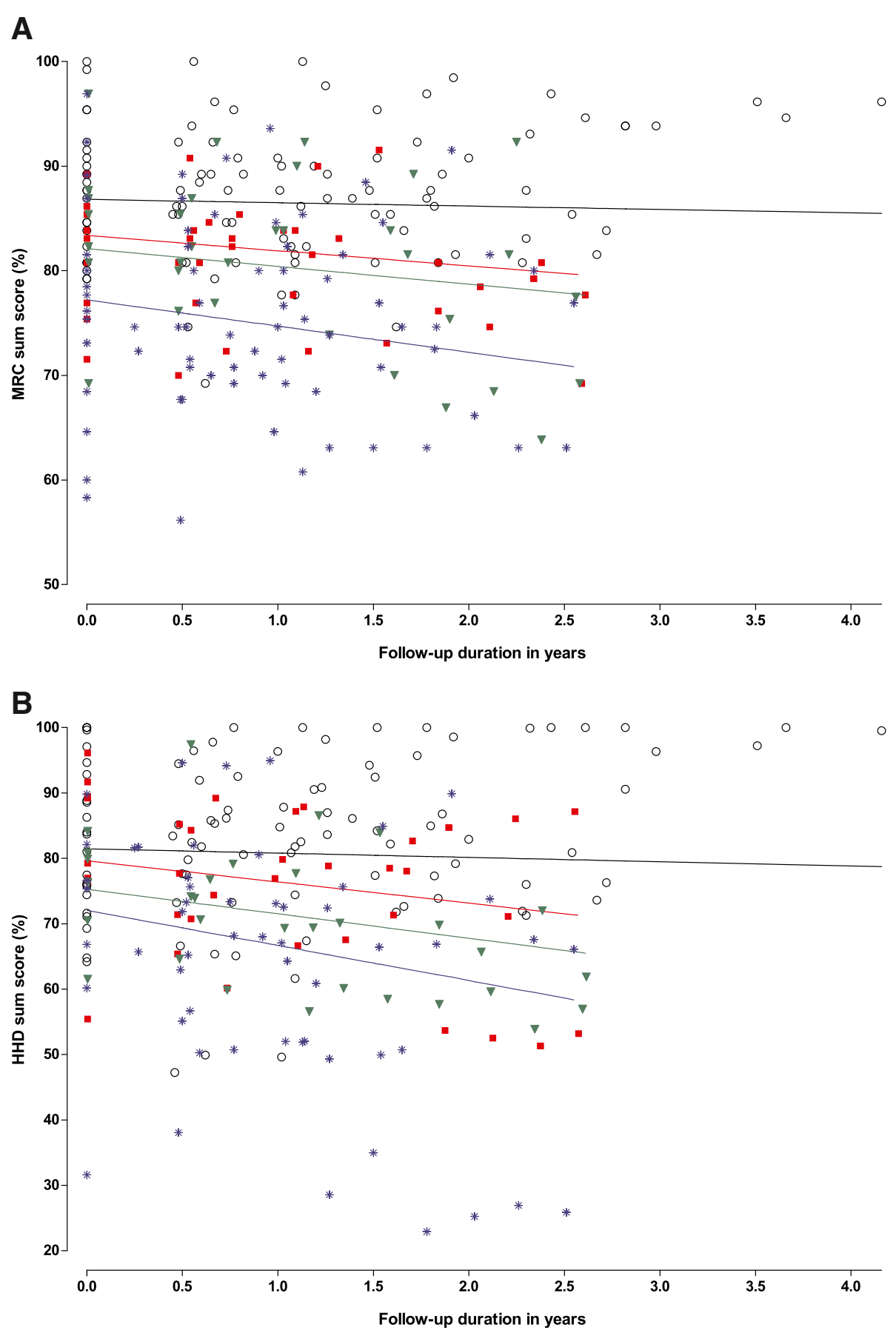

Figure 3 Longitudinal changes in muscle strength. Rate of disease progression measured by manual muscle testing (MRC sumscore) (A) and hand-held dynamometry (HHD sumscore) (B) related to follow-up duration measured from time of inclusion in the study for 66 adults with Pompe disease. The figure shows the measured values and regression lines at group level for the following subgroups: 1) Patients with normal pulmonary function (FVC $\geq 80 \%$ predicted) and disease duration $<15$ years (circles, black line); 2 ) patients with normal pulmonary function (FVC $\geq 80 \%$ predicted) and disease duration $\geq 15$ years (red squares, red line); 3 ) patients with abnormal pulmonary function (FVC $<80 \%$ predicted) and disease duration $<15$ years (green triangles, green line); and 4) patients with abnormal pulmonary function (FVC $<80 \%$ predicted) and disease duration $\geq 15$ years (blue asterisks, blue line). 

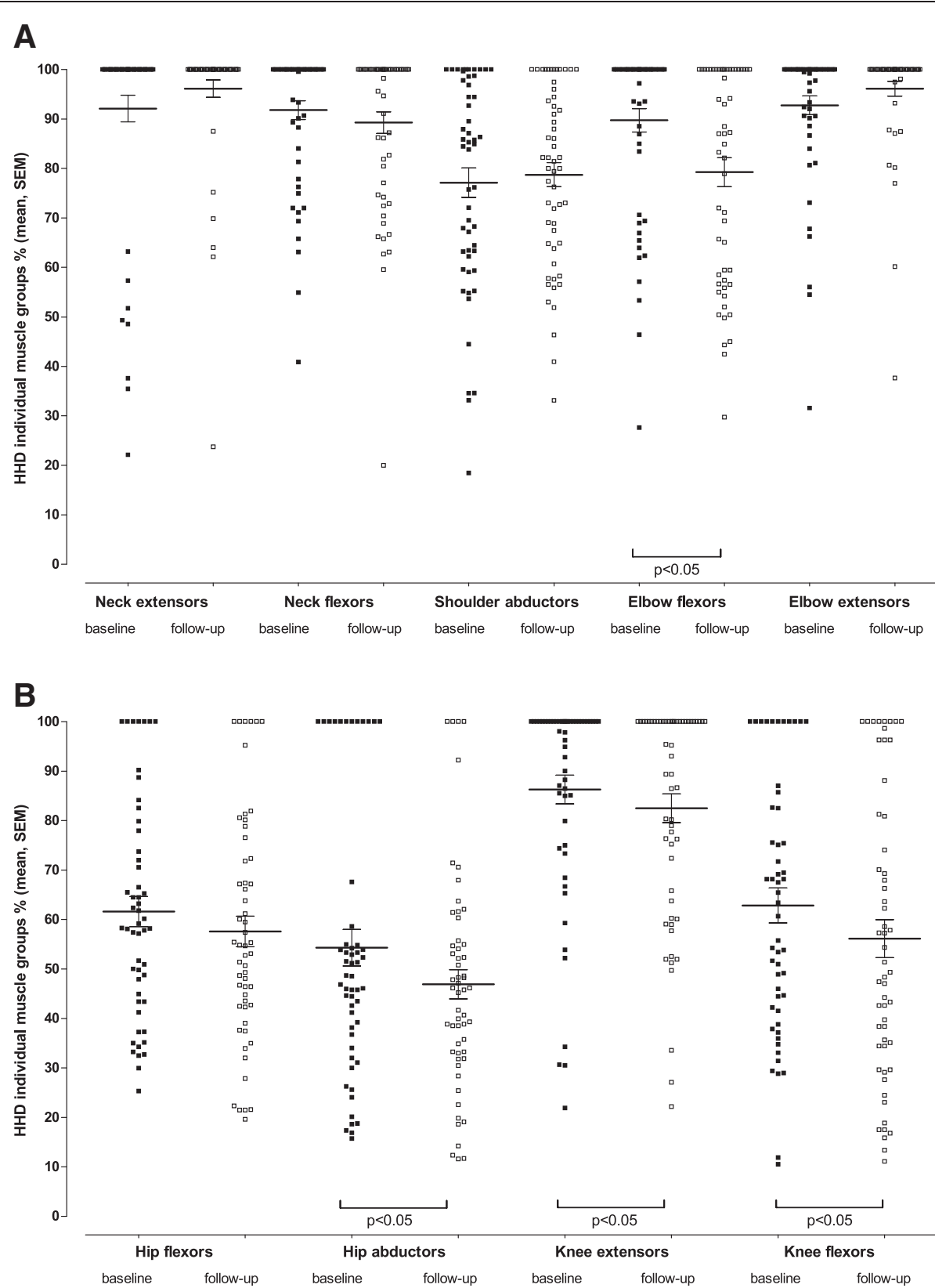

Figure 4 Muscle strength in individual muscle groups measured by hand-held dynamometry. Values for individual patients are shown at baseline (black squares) and during follow-up (last measured value) (open squares). Mean and standard error of the mean are given for each muscle group.

myogenic ptosis to be bilateral, it was unilateral in twothirds of our patients.

Despite the fact that bulbar muscle weakness is reported only occasionally in adult Pompe patients $[28,32]$, twenty-eight percent of the patients in our cohort had distinct bulbar muscle weakness. These patients are at risk of pulmonary complications.

One third of patients had prominent scapular winging, which is in line with several recent reports [32,33]. Many of these patients also had bulbar muscle involvement and severer weakness of the shoulder-girdle muscles than patients without scapular winging; these features are reminiscent of FSHD. If patients with such a "pseudo-FSHD" phenotype are overlooked, diagnosis may be delayed. However, the asymmetrical distribution of muscle weakness, the relatively common involvement of the distal muscles of the lower limbs, and the absence of severe or relatively severe pulmonary involvement in FSHD will generally allow the two diseases to be diagnosed correctly [34]. 


\begin{tabular}{|c|c|c|c|c|c|c|c|c|c|c|c|c|c|c|c|}
\hline \multirow[b]{2}{*}{ Total group } & \multicolumn{3}{|c|}{ MRC sumscore } & \multicolumn{3}{|c|}{ HHD sumscore } & \multicolumn{3}{|c|}{ QMFT score } & \multicolumn{3}{|c|}{ FVC sitting position } & \multicolumn{3}{|c|}{ FVC supine position } \\
\hline & $n$ & $\begin{array}{l}\text { Annual } \\
\text { change } \\
\text { (\%/year) }\end{array}$ & $95 \% \mathrm{Cl}$ & $n$ & $\begin{array}{l}\text { Annual } \\
\text { change } \\
\text { (\%/year) }\end{array}$ & $95 \% \mathrm{Cl}$ & $n$ & $\begin{array}{l}\text { Annual } \\
\text { change } \\
\text { (\%/year) }\end{array}$ & $95 \% \mathrm{Cl}$ & $n$ & $\begin{array}{l}\text { Annual } \\
\text { change } \\
\text { (\%/year) }\end{array}$ & $95 \% \mathrm{Cl}$ & $n$ & $\begin{array}{l}\text { Annual } \\
\text { change } \\
\text { (\%/year) }\end{array}$ & $95 \% \mathrm{Cl}$ \\
\hline & 65 & -1.30 & -1.95 to -0.66 & 55 & -2.6 & -3.72 to -1.45 & 62 & 0.05 & -0.76 to 0.86 & 59 & -1.04 & -2.14 to 0.06 & 54 & -1.30 & -2.42 to -0.19 \\
\hline Subgroups & $n$ & $\begin{array}{l}\begin{array}{l}\text { Annual } \\
\text { change } \\
\text { (\%/year) }\end{array}\end{array}$ & & $n$ & $\begin{array}{l}\text { Annual } \\
\text { change } \\
\text { (\%/year) }\end{array}$ & & $n$ & $\begin{array}{l}\begin{array}{l}\text { Annual } \\
\text { change } \\
\text { (\%/year) }\end{array}\end{array}$ & & $n$ & $\begin{array}{l}\text { Annual } \\
\text { change } \\
\text { (\%/year) }\end{array}$ & & $n$ & $\begin{array}{l}\begin{array}{l}\text { Annual } \\
\text { change } \\
\text { (\%/year) }\end{array}\end{array}$ & \\
\hline \multicolumn{16}{|l|}{ Gender } \\
\hline - Female & 36 & -1.41 & & 31 & -2.97 & & 37 & -0.22 & & 36 & -1.38 & & 33 & -2.27 & \\
\hline - Male & 29 & -1.08 & & 24 & -1.99 & & 25 & 0.57 & & 23 & -0.45 & & 21 & 0.35 & \\
\hline \multicolumn{16}{|c|}{ Age at study entry ${ }^{a}$} \\
\hline$\cdot<50$ years & 34 & -1.39 & & 31 & -2.06 & & 33 & -0.17 & & 33 & -1.34 & & 31 & -2.22 & \\
\hline$\cdot \geq 50$ years & 31 & -1.21 & & 24 & -3.29 & & 29 & 0.30 & & 26 & -0.69 & & 23 & -0.08 & \\
\hline \multicolumn{16}{|c|}{ Disease duration at study entry ${ }^{a}$} \\
\hline$\cdot<15$ years & 34 & $-0.70^{c}$ & & 31 & $-1.95^{\mathrm{e}}$ & & 34 & -0.07 & & 35 & -1.36 & & 33 & -1.37 & \\
\hline$\cdot \geq 15$ years & 31 & $-2.09^{c}$ & & 24 & $-4.18^{\mathrm{e}}$ & & 28 & 0.17 & & 24 & -0.60 & & 21 & -1.16 & \\
\hline \multicolumn{16}{|c|}{ FVC (sitting) at study entry } \\
\hline $\begin{array}{l}\cdot \geq 80 \% \\
\text { predicted }\end{array}$ & 33 & $-0.62^{d}$ & & 32 & $-1.43^{f}$ & & 33 & -0.21 & & 33 & -1.09 & & 31 & -1.59 & \\
\hline $\begin{array}{l}\cdot<80 \% \\
\text { predicted }\end{array}$ & 32 & $-2.21^{d}$ & & 23 & $-4.52^{f}$ & & 29 & 0.31 & & 26 & -0.89 & & 23 & -0.92 & \\
\hline \multicolumn{16}{|c|}{ Ventilation at study entry } \\
\hline - No & 49 & -1.12 & & 46 & -2.50 & & 50 & 0.24 & & 50 & -1.30 & & 47 & -1.50 & \\
\hline - Yes & 16 & -1.83 & & 9 & -3.55 & & 12 & -0.70 & & 9 & 1.07 & & 7 & 0.32 & \\
\hline \multicolumn{16}{|c|}{ Wheelchair use at study entry } \\
\hline - No & 47 & -0.94 & & 44 & -2.28 & & 47 & -0.39 & & 47 & -0.98 & & 43 & -0.99 & \\
\hline - Yes & 18 & -2.36 & & 11 & -3.92 & & 15 & 1.44 & & 12 & -1.22 & & 11 & -2.57 & \\
\hline \multicolumn{16}{|c|}{ MRC / HHD sum score at study entry ${ }^{b}$} \\
\hline $\begin{array}{l}-<33 \text { rd } \\
\text { percentile }\end{array}$ & 18 & -1.27 & & 10 & -2.06 & & 20 & 0.49 & & 12 & -0.30 & & 9 & -1.59 & \\
\hline $\begin{array}{l}\text {-33rd to 66th } \\
\text { percentile }\end{array}$ & 23 & -1.31 & & 22 & -4.34 & & 23 & -0.06 & & 23 & -2.40 & & 21 & -2.01 & \\
\hline $\begin{array}{l}\cdot \geq 66 \text { th } \\
\text { percentile }\end{array}$ & 24 & -0.98 & & 23 & -1.56 & & 19 & -0.41 & & 24 & -0.34 & & 24 & -0.63 & \\
\hline $\begin{array}{l}\text { MRC: Medical Re } \\
\text { tertiles. } n \text { repres } \\
\text { were missing (e. } \\
\text { by } 5 \text { patients wh } \\
\text { Data shown are } \\
\text { disease duration }\end{array}$ & & $\begin{array}{l}\text { il; } H H D: \mathrm{HC}_{\mathrm{c}} \\
\text { ber of pati } \\
\text { erity of } \mathrm{mL} \\
\text { ry functior }\end{array}$ & $\begin{array}{l}\text { weakness or inj } \\
\text { as already severe }\end{array}$ & est & $\begin{array}{l}\text { Quick Mo } \\
\text { lable for ea } \\
\text { even invasi } \\
\text { ed in sitting }\end{array}$ & $\begin{array}{l}\text { Function Test; } F \\
\text { specific measure } \\
\text { ly ventilated pati } \\
\text { osition. }\end{array}$ & & $\begin{array}{l}\text { Vital Capa } \\
\text { muscle str } \\
\text { liable meas }\end{array}$ & $\begin{array}{l}\text { y; Cl: confidence } \\
\text { gth, no sumscor } \\
\text { ements of FVC c }\end{array}$ & cuma & $\begin{array}{l}{ }^{d} \text { the media } \\
\text { lculated if } m \\
\text { performed. }\end{array}$ & $\begin{array}{l}\text { was taken as th } \\
\text { either could testir }\end{array}$ & cut-of & $\begin{array}{l}\text { point. }{ }^{b} \text { cate } \\
\text { more individ } \\
\text { e supine pos }\end{array}$ & $\begin{array}{l}\text { orization in } \\
\text { al muscle groups } \\
\text { on be endured } \\
\text { os based on }\end{array}$ \\
\hline
\end{tabular}



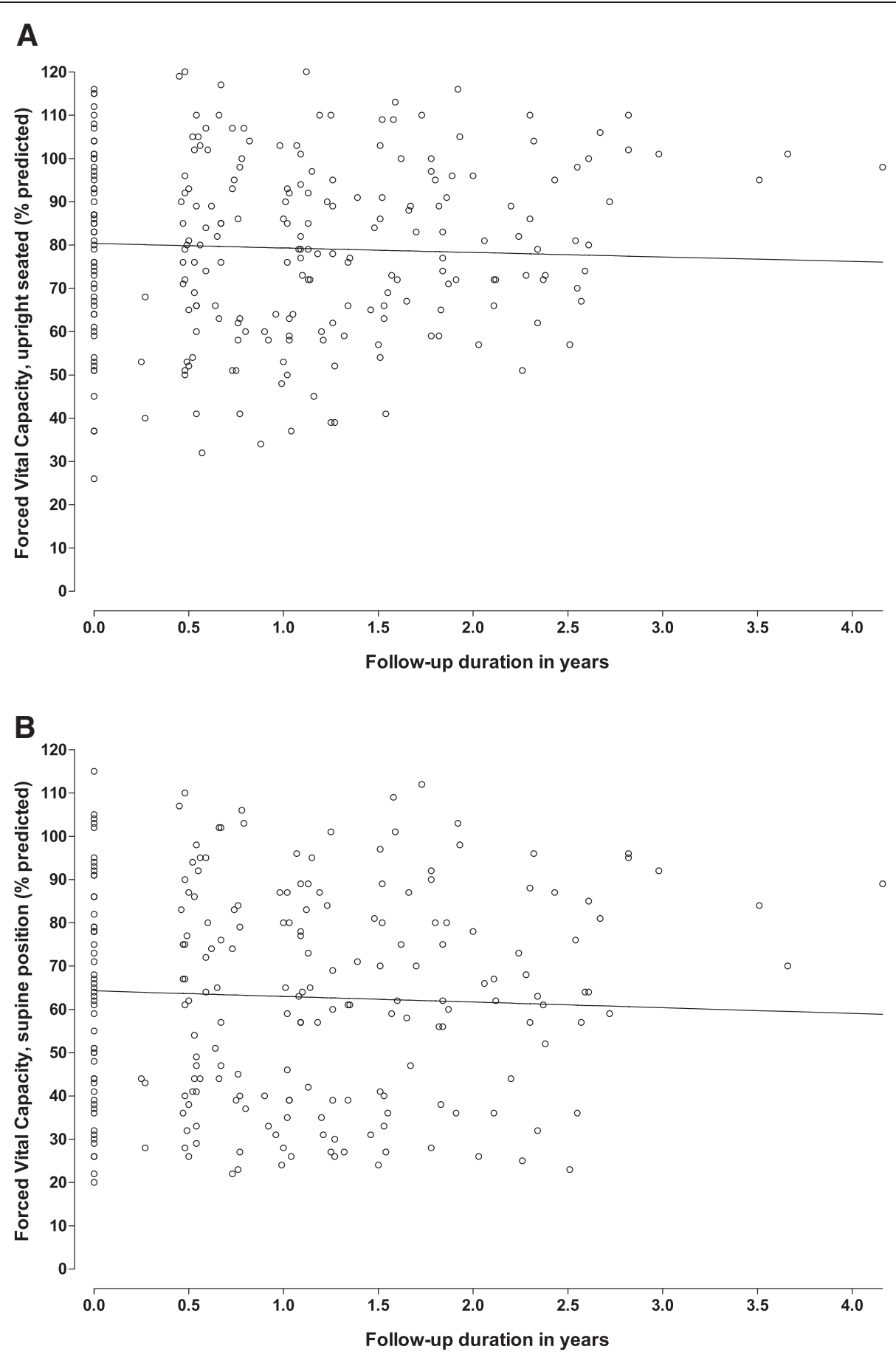

Figure $\mathbf{5}$ Longitudinal changes in pulmonary function. Decline in pulmonary function in the upright seated (A) and supine (B) positions related to follow-up duration. Circles represent the measured values, the line represents the mean regression line at a group level.

Serum CK activity was normal in 10 patients, confirming that a normal serum CK does not rule out Pompe disease [35-37]. In early stages of the disease, however, normal serum CK is quite uncommon. Although we did not systematically perform electromyography or muscle biopsies, it is well known that these may reveal no or only non-specific abnormalities in a considerable number of patients $[38,39]$. Therefore, measurement of acid $\alpha$-glucosidase activity and mutation analysis remain essential to confirm the diagnosis. 


\section{Natural disease course}

Although the average follow-up duration of 19 months seems rather short for a chronic disorder such as Pompe disease, it is the longest prospective follow-up ever carried out in "late-onset" Pompe disease. Moreover, as many patients are now treated with enzyme replacement therapy, prospective data on the natural course of the disease over a longer period of time are now impossible to obtain.

We found a significant worsening of muscle strength, reflected by declines in MRC sumscore (mean decline $-1.3 \% \mathrm{pp} / \mathrm{y}$ ) and HHD sumscore (mean decline $-2.6 \%$ $\mathrm{pp} / \mathrm{y})$. Although we found significant changes in muscle strength and some patients became wheelchair or ventilator dependent during follow-up, the QMFT did not indicate a deterioration in limb-girdle muscle function. There may be two main reasons for this. First, the decline in muscle strength may have been too small to cause changes in functional daily activities within the observed time-span. Second, although the QMFT showed a good discriminative ability and good responsiveness to change after start of enzyme replacement therapy, it may not be sensitive enough to reflect minor changes in strength in functional changes during the natural course [18].

Mechanical ventilation became necessary in four of the 67 hitherto un-ventilated patients, eight patients needed to increase their number of hours of ventilation, and one patient died due to respiratory complications. Despite this indication that pulmonary function clearly worsened during the time-span of the study, our findings regarding the yearly decline seem somewhat lower than those of other studies. [13,27] This may have been due to our method of patient selection: in the present study participation was open to all adult patients with a confirmed diagnosis of Pompe disease, including those with very limited pulmonary function who were invasively ventilated 24 hours a day. Although this reflects the spectrum of disease encountered in daily practice, one would expect further deterioration of pulmonary function in these patients to be minimal, thereby partly obscuring decline in the total group. Secondly, when enzyme replacement therapy became commercially available, we decided first to treat the most severely affected patients and patients with a rapid decline in pulmonary function and muscle strength, while patients with a slow disease course were started on ERT at a later stage. As a result, the length of prospective follow-up for the most severely affected patients was somewhat shorter (1.1 years on average) than for the least affected patients (1.7 years on average, the longest follow-up being 4.2 years). Another factor that could have influenced the estimated rate of decline is the fact that data on seven patients who participated in the placebo arm of the randomized controlled trial on the safety and efficacy of alglucosidase alfa in late-onset Pompe disease were included in the present analyses. However, a second analysis, excluding these patients to overcome a possible placebo effect, led to similar estimates of the rate at which muscle weakness and pulmonary dysfunction progress (not shown).

It should be noted that all patients except one had the c.-32-13T $>$ G (IVS1-13T $>$ G) mutation in combination with a null allele. Although this is the most common genotype in adult Pompe patients - present in 68-93\% of patients $[27,40,41]$ - the estimated rate of disease progression may not apply to patients with different genotypes.

\section{Predictors for disease outcome and disease course variability}

Longer disease duration ( $\geq 15$ years) and pulmonary dysfunction (FVC $<80 \%$ ) were shown to be associated with a faster decline in muscle strength. Our results thus support those of the only other prospective study in adult Pompe patients, which found baseline status and duration of illness to be the most important predictors of disease severity and disease progress [27].

A subset of patients with shorter average disease duration and better baseline status did not deteriorate during follow-up, indicating that there might be a stable phase of several years before a gradual decline inevitably occurs. This raises an interesting dilemma regarding the best time to start ERT. [42] On the one hand, in patients who are only mildly affected and whose condition is stable, one might advocate that this - costly - lifelong treatment be postponed. On the other hand, studies measuring the effect of ERT show a trend toward better outcome in patients who were in a relatively good condition at the start of treatment. $[11,13,14]$ On the basis of our results, we suggest to start ERT in all patients with pulmonary dysfunction and in patients with progressive muscle weakness, whereas in patients with minimal weakness, or in patients with solely elevated laboratory parameters treatment may be postponed, provided that they are monitored regularly. At our center, all patients undergo evaluation of muscle strength, pulmonary function, cardiac function, and hearing at referral, and evaluation of progression of muscle weakness and pulmonary dysfunction every three months thereafter.

\section{Conclusions}

In summary, since the approval of enzyme replacement therapy in Pompe disease, early recognition of affected individuals has gained importance. The typical limbgirdle type muscle weakness - including prominent involvement of the trunk musculature - combined with early and disproportionate pulmonary involvement 
relative to the degree of skeletal muscle weakness should raise the suspicion of Pompe disease. Although these are the most salient characteristics, less familiar features such as ptosis, scapular winging and bulbar weakness are far more common than generally thought. If these are recognized properly, timely diagnosis will be facilitated. Longer disease duration and reduced pulmonary function stand out as the most important factors for a rapid decline in muscle strength, which may aid in deciding whom to treat and when.

\begin{abstract}
Abbreviations
4-MU: 4-methylumbelliferyl-a-D-glucopyranoside; ATS: American Thoracic Society; CCMO: Central Committee on Research Involving Human Subjects in the Netherlands; CK: Creatine Kinase; ERS: European Respiratory Society; ERT: Enzyme Replacement Therapy; FSHD: FacioScapuloHumeral Dystrophy; FVC: Forced Vital Capacity; GAA: Gene coding for acid alpha-glucosidase; HHD: Hand-held dynamometry; LGMD: Limb-Girdle Muscular Dystrophy; MRC: Medical Research Council; Pp/y: Percentage points per year; QMFT: Quick Motor Function Test; QMT: Quantitative Muscle Testing.
\end{abstract}

\section{Competing interests}

MLCH, ATVdP, and AJJR have provided consulting services to, and have received research funding from Genzyme Corporation, a Sanofi company, under an agreement between Genzyme and Erasmus MC University Medical Center, Rotterdam, the Netherlands. The other authors declare that they have no competing interests.

\section{Authors' contributions}

NAMEvdB participated in study design, recruitment of patients, data collection, statistical analyses, data interpretation, and drafting and revising the manuscript for important intellectual content. JMdV participated in recruitment of patients, data collection, statistical analyses, data interpretation, and drafting and revising the manuscript for important intellectual content. MLCH participated in study design, data interpretation, and revising the manuscript for important intellectual content. WCJH participated in study design, supervised the statistical analysis, and revising the manuscript for important intellectual content. MAK participated in data collection, data interpretation, and revising manuscript for important intellectual content. JHJW, MdV, BGMvE, JBMK, AJvdK, NCN, CGF, and JJGMV participated in recruitment of patients, data interpretation, and revising the manuscript for important intellectual content. AJJR, ATvdP and PAvD conceived of the study and participated in its design and coordination, data interpretation, and revising manuscript for important intellectual content. All authors read and approved the final manuscript.

\section{Acknowledgements}

The authors thank all patients for participating in the study. For their referral of patients, we would like to thank the following neurologists in the Netherlands: W.L. van der Pol and G.J. Biessels (Rudolf Magnus Institute of Neurosciences, University Medical Center Utrecht, Utrecht); H.J. Schelhaas (Radboud University Nijmegen Medical Centre, Nijmegen); A.R. Wintzen (Leiden University Medical Center, Leiden); W.J.H.M. Grosveld (Reinier de Graaf Groep, Delft); G. Hageman (Medisch Spectrum Twente, Enschede); A.M. Boon (Admiraal de Ruyter Hospital Goes); H. Kerkhoff (Albert Schweitzer Hospital, Dordrecht); L.G.F. Sinnege (Medical Center Leeuwarden, Leeuwarden); N.M. Vlam (TweeSteden Hospital, Tilburg); and A. van der Zwart (Haga Hospital, The Hague). For his referral of patients, we would also like to thank J. de Bleecker (Department of Neurology, University Hospital Gent, Belgium). We also thank David Alexander for his critical reading of the manuscript, and Geert Willems for the layout of the figures.

\section{Funding}

Funding was obtained from the Erasmus MC Revolving Fund [Project No. 1054 to NAMEvdB]; ZonMw - The Netherlands Organisation for Health Research and Development [Project No. 152001005]; the Dutch TI Pharma initiative "Sustainable Orphan Drug Development through Registries and Monitoring" [Project No. T6-208]; European Union, $7^{\text {th }}$ Framework
Programme "EUCLYD" - a European Consortium for Lysosomal Storage Diseases [health F2/2008 grant agreement 201678]; and the Prinses Beatrix Fonds [Project No. OP07-08].

\section{Author details}

1Department of Neurology, Center for Lysosomal and Metabolic Diseases, Erasmus MC University Medical Center, 's-Gravendijkwal 230, 3015 CE, Rotterdam, the Netherlands. ${ }^{2}$ Department of Pediatrics, Center for Lysosomal and Metabolic Diseases, Erasmus MC - Sophia Children's Hospital, University Medical Center, Rotterdam, the Netherlands. ${ }^{3}$ Department of Epidemiology and Biostatistics, Erasmus MC University Medical Center, Rotterdam, the Netherlands. ${ }^{4}$ Department of Clinical Genetics, Center for Lysosomal and Metabolic Diseases, Erasmus MC University Medical Center, Rotterdam, the Netherlands. ${ }^{5}$ Department of Neurology, Rudolf Magnus Institute of Neurosciences, University Medical Center Utrecht, Utrecht, the Netherlands. ${ }^{6}$ Department of Neurology, Academic Medical Center, Amsterdam, the Netherlands. ${ }^{7}$ Department of Neurology, Radboud University Nijmegen Medical Center, Nijmegen, the Netherlands. ${ }^{8}$ Department of Neurology, University Medical Center Groningen, Groningen, the Netherlands. ${ }^{9}$ Department of Neurology, Maastricht University Medical Center, Maastricht, the Netherlands. ${ }^{10}$ Department of Neurology, Leiden University Medical Center, Leiden, the Netherlands.

Received: 1 October 2012 Accepted: 6 November 2012 Published: 12 November 2012

\section{References}

1. Pompe JC: Over idiopathische hypertrofie van het hart. Ned Tijdschr Geneeskd 1932, 76:304-311.

2. Engel AG, Gomez MR, Seybold ME, Lambert EH: The spectrum and diagnosis of acid maltase deficiency. Neurology 1973, 23:95-106.

3. van der Ploeg AT, Reuser AJ: Pompe's disease. Lancet 2008, 372:1342-1353.

4. Engel AG: Franzini-Armstrong: Myology. New York: McGraw-Hill; 2004.

5. Amalfitano A, Bengur AR, Morse RP, Majure JM, Case LE, Veerling DL, Mackey J, Kishnani P, Smith W, McVie-Wylie A, Sullivan JA, Hoganson GE, Phillips JA 3rd, Schaefer GB, Charrow J, Ware RE, Bossen EH, Chen YT: Recombinant human acid alpha-glucosidase enzyme therapy for infantile glycogen storage disease type II: results of a phase I/II clinical trial. Genet Med 2001, 3:132-138.

6. Kishnani PS, Nicolino M, Voit T, Rogers RC, Tsai AC, Waterson J, Herman GE, Amalfitano A, Thurberg BL, Richards S, Davison M, Corzo D, Chen YT: Chinese hamster ovary cell-derived recombinant human acid alphaglucosidase in infantile-onset Pompe disease. J Pediatr 2006, 149:89-97.

7. Kishnani PS, Corzo D, Nicolino M, Mandel H, Hwu WL, Leslie N, Levine J, Spencer C, McDonald M, Li J, Dumontier J, Halberthal M, Chien YH, Hopkin R, Vijayaraghavan S, Gruskin D, Bartholomew D, van der Ploeg A, Clancy JP, Parini R, Morin G, Beck M, De la Gastine GS, Jokic M, Thurberg B, Richards S, Bali D, Davison M, Worden MA, Chen YT, Wraith JE: Recombinant human acid [alpha]-glucosidase: major clinical benefits in infantile-onset Pompe disease. Neurology 2007, 68:99-109.

8. van den Hout H, Reuser AJ, Vulto AG, Loonen MC, Cromme-Dijkhuis A, van der Ploeg AT: Recombinant human alpha-glucosidase from rabbit milk in Pompe patients. Lancet 2000, 356:397-398.

9. Bembi B, Pisa FE, Confalonieri M, Ciana G, Fiumara A, Parini R, Rigoldi M, Moglia A, Costa A, Carlucci A, Danesino C, Pittis MG, Dardis A, Ravaglia S: Long-term observational, non-randomized study of enzyme replacement therapy in late-onset glycogenosis type II. J Inherit Metab Dis 2010, 33:727-735

10. Orlikowski $D$, Pellegrini N, Prigent $H$, Laforêt $P$, Carlier R, Carlier $P$, Eymard $B$, Lofaso F, Annane D: Recombinant human acid alpha-glucosidase (rhGAA) in adult patients with severe respiratory failure due to Pompe disease. Neuromuscul Disord 2011, 21:477-482.

11. Strothotte S, Strigl-Pill N, Grunert B, Kornblum C, Eger K, Wessig C, Deschauer M, Breunig F, Glocker FX, Vielhaber S, Brejova A, Hilz M, Reiners K, Müller-Felber W, Mengel E, Spranger M, Schoser B: Enzyme replacement therapy with alglucosidase alfa in 44 patients with late-onset glycogen storage disease type 2: 12-month results of an observational clinical trial. J Neurol 2010, 257:91-97.

12. van Capelle Cl, van der Beek NA, Hagemans ML, Arts WF, Hop WC, Lee P, Jaeken J, Frohn-Mulder IM, Merkus PJFM, Corzo D, Puga AC, Reuser AJ, van der Ploeg AT: Effect of enzyme therapy in juvenile patients with Pompe 
disease: a three-year open-label study. Neuromuscul Disord 2010, 20:775-782.

13. van der Ploeg AT, Clemens PR, Corzo D, Escolar DM, Florence J, Groeneveld GJ, Herson S, Kishnani PS, Laforet P, Lake SL, Lange DJ, Leshner RT, Mayhew JE, Morgan C, Nozaki K, Park DJ, Pestronk A, Rosenbloom B, Skrinar A, van Capelle $\mathrm{Cl}$, van der Beek NA, Wasserstein M, Zivkovic SA: A randomized study of alglucosidase alfa in late-onset Pompe's disease. $N$ Engl J Med 2010, 362:1396-1406.

14. Winkel LP, van den Hout JM, Kamphoven JH, Disseldorp JA, Remmerswaal M, Arts WF, Loonen MC, Vulto AG, van Doorn PA, de Jong G, Hop W, Smit GP, Shapira SK, Boer MA, van Diggelen OP, Reuser AJ, van der Ploeg AT: Enzyme replacement therapy in late-onset Pompe's disease: a three-year follow-up. Ann Neurol 2004, 55:495-502.

15. van der Beek NA, Hagemans ML, Reuser AJ, Hop WC, van der Ploeg AT, van Doorn PA, Wokke $\mathrm{JH}$ : Rate of disease progression during long-term follow-up of patients with late-onset Pompe disease. Neuromuscul Disord 2009, 19:113-117.

16. Medical Resarch Council: Aids to the examination of the peripheral nervous system. Memorandum no. 45. London: Her Majesty's Stationary Office; 1976

17. van der Ploeg RJ, Fidler V, Oosterhuis HJ: Hand-held myometry: reference values. J Neurol Neurosurg Psychiatry 1991, 54:244-247.

18. van Capelle $\mathrm{Cl}$, van der Beek NA, de Vries JM, van Doorn PA, Duivenvoorden HJ, Leshner RT, Hagemans ML, van der Ploeg AT: The quick motor function test: a new tool to rate clinical severity and motor function in Pompe patients. J Inherit Metab Dis 2012, 35:317-323.

19. Miller MR, Hankinson J, Brusasco V, Burgos F, Casaburi R, Coates A, Crapo R, Enright $P$, van der Grinten $C P$, Gustafsson $P$, Jensen $R$, Johnson DC, Maclntyre N, McKay R, Navajas D, Pedersen OF, Pellegrino R, Viegi G, Wanger J: Standardisation of spirometry. Eur Respir J 2005, 26:319-338.

20. Quanjer PH, Tammeling GJ, Cotes JE, Pedersen OF, Peslin R, Yernault JC: Lung volumes and forced ventilatory flows. Report Working Party Standardization of Lung Function Tests, European Community for Steel and Coal. Official Statement of the European Respiratory Society. Eur Respir J 1993, 16(S):5-40.

21. Soliman OI, van der Beek NA, van Doorn PA, Vletter WB, Nemes A, van Dalen BM, ten Cate FJ, van der Ploeg AT, Geleijnse ML: Cardiac involvement in adults with Pompe disease. J Intern Med 2008, 264:333-339.

22. van der Beek NA, Soliman Ol, van Capelle Cl, Geleijnse ML, Vletter WB, Kroos MA, Reuser AJ, Frohn-Mulder IM, van Doorn PA, van der Ploeg AT: Cardiac evaluation in children and adults with Pompe disease sharing the common c.-32-13T>G genotype rarely reveals abnormalities. J Neuro/ Sci 2008, 275:46-50

23. van der Beek NA, van Capelle $\mathrm{Cl}$, van der Velden-van Etten $\mathrm{Kl}$, Hop WC, van den Berg B, Reuser AJ, van Doorn PA, van der Ploeg AT, Stam H: Rate of progression and predictive factors for pulmonary outcome in children and adults with Pompe disease. Mol Genet Metab 2011, 104:129-136.

24. Carlier RY, Laforet P, Wary C, Mompoint D, Laloui K, Pellegrini N, Annane D, Carlier PG, Orlikowski D: Whole-body muscle MRI in 20 patients suffering from late onset Pompe disease: Involvement patterns. Neuromuscul Disord 2011, 21:791-799.

25. de Jager AE, van der Vliet TM, van der Ree TC, Oosterink BJ, Loonen MC: Muscle computed tomography in adult-onset acid maltase deficiency. Muscle Nerve 1998, 21:398-400.

26. Pichiecchio A, Uggetti C, Ravaglia S, Egitto MG, Rossi M, Sandrini G, Danesino C: Muscle MRI in adult-onset acid maltase deficiency. Neuromuscul Disord 2004, 14:51-55.

27. Wokke JH, Escolar DM, Pestronk A, Jaffe KM, Carter GT, van den Berg LH, Florence JM, Mayhew J, Skrinar A, Corzo D, Laforet P: Clinical features of late-onset Pompe disease: a prospective cohort study. Muscle Nerve 2008, 38:236-245.

28. Barnes D, Hughes RA, Spencer GT: Adult-onset acid maltase deficiency with prominent bulbar involvement and ptosis. J R Soc Med 1993 86:50

29. Ravaglia S, Bini P, Garaghani KS, Danesino C: Ptosis in Pompe disease: common genetic background in infantile and adult series. J Neuroophthalmol 2010, 30:389-390.

30. de Wilde F, d'Haens M, Smet H, Martin JJ, Tassignon MJ: Surgical treatment of myogenic blepharoptosis. Bull Soc Belge Ophtalmol 1995, 255:139-146.
31. Groen WB, Leen WG, Vos AM, Cruysberg JR, van Doorn PA, van Engelen BG: Ptosis as a feature of late-onset glycogenosis type II. Neurology 2006, 67:2261-2262

32. Schüller A, Wenninger S, Strigl-Pill N, Schoser B: Toward deconstructing the phenotype of late-onset Pompe disease. Am J Med Genet C Semin Med Genet 2012, 160:80-88

33. Byrne BJ, Kishnani PS, Case LE, Merlini L, Müller-Felber W, Prasad S, van der Ploeg A: Pompe disease: design, methodology, and early findings from the Pompe Registry. Mol Genet Metab 2011, 103:1-11.

34. Tawil R, van der Maarel SM: Facioscapulohumeral muscular dystrophy. Muscle Nerve 2006, 34:1-15.

35. Muller-Felber W, Horvath R, Gempel K, Podskarbi T, Shin Y, Pongratz D, Walter MC, Baethmann M, Schlotter-Weigel B, Lochmüller H, Schoser B: Late onset Pompe disease: clinical and neurophysiological spectrum of 38 patients including long-term follow-up in 18 patients. Neuromuscul Disord 2007, 17:698-706.

36. Winkel LP, Hagemans ML, van Doorn PA, Loonen MC, Hop WJ, Reuser AJ, van der Ploeg AT: The natural course of non-classic Pompe's disease; a review of 225 published cases. J Neurol 2005, 252:875-884.

37. Ausems MG, Lochman P, van Diggelen OP, Ploos van Amstel HK, Reuser AJ, Wokke $\mathrm{JH}$ : A diagnostic protocol for adult-onset glycogen storage disease type II. Neurology 1999, 52:851-853.

38. Schoser BG, Müller-Höcker J, Horvath R, Gempel K, Pongratz D, Lochmüller $H$, Müller-Felber W: Adult-onset glycogen storage disease type 2: clinicopathological phenotype revisited. Neuropathol Appl Neurobiol 2007, 33:544-559.

39. Hobson-Webb LD, Dearmey S, Kishnani PS: The clinical and electrodiagnostic characteristics of Pompe disease with post-enzyme replacement therapy findings. Clin Neurophysio/ 2011, 122:2312-2317.

40. Huie ML, Chen AS, Tsujino S, Shanske S, DiMauro S, Engel AG, Hirschhorn R: Aberrant splicing in adult onset glycogen storage disease type II (GSDII): molecular identification of an IVS1 $(-13 \mathrm{~T}->\mathrm{G})$ mutation in a majority of patients and a novel IVS10 (+1GT->CT) mutation. Hum Mol Genet 1994, 3:2231-2236.

41. Montalvo AL, Bembi B, Donnarumma M, Filocamo M, Parenti G, Rossi M, Merlini L, Buratti E, De Filippi P, Dardis A, Stroppiano M, Ciana G, Pittis MG: Mutation profile of the GAA gene in 40 Italian patients with late onset glycogen storage disease type II. Hum Mutat 2006, 27:999-1006.

42. Laloui K, Wary C, Carlier RY, Hogrel JY, Caillaud C, Laforet P: Making diagnosis of Pompe disease at a presymptomatic stage: to treat or not to treat? Neurology 2011, 77:594-595.

\section{doi:10.1186/1750-1172-7-88}

Cite this article as: van der Beek et al: Clinical features and predictors for disease natural progression in adults with Pompe disease: a nationwide prospective observational study. Orphanet Journal of Rare Diseases 2012 7:88

\section{Submit your next manuscript to BioMed Central and take full advantage of:}

- Convenient online submission

- Thorough peer review

- No space constraints or color figure charges

- Immediate publication on acceptance

- Inclusion in PubMed, CAS, Scopus and Google Scholar

- Research which is freely available for redistribution 